PROTECTING LIFE on EARTH 


\section{THE STEPHEN BECHTEL FUND}

IMPRINT IN ECOLOGY AND THE ENVIRONMENT

The Stephen Bechtel Fund has established this imprint to promote understanding and conservation of our natural environment. 


\title{
PROTECTING LIFE on EARTH
}

\section{An Introduction to the Science of Conservation}

\author{
Michael P. Marchetti \\ Peter B. Moyle
}

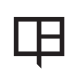

UNIVERSITY OF CALIFORNIA PRESS

Berkeley Los Angeles London 
The publisher gratefully acknowledges the generous contribution to this book provided by the Stephen Bechtel Fund.

University of California Press, one of the most distinguished university presses in the United States, enriches lives around the world by advancing scholarship in the humanities, social sciences, and natural sciences. Its activities are supported by the UC Press Foundation and by philanthropic contributions from individuals and institutions. For more information, visit www.ucpress.edu.

University of California Press

Berkeley and Los Angeles, California

University of California Press, Ltd.

London, England

(C) 2010 by the Regents of the University of California

Library of Congress Cataloging-in-Publication Data

Marchetti, Michael P.

Protecting life on Earth : an introduction to the science of conservation / Michael P. Marchetti, Peter B. Moyle.

p. cm.

Includes bibliographical references and index.

ISBN 978-0-520-26432-8 (pbk. : alk. paper)

1. Wildlife conservation-Textbooks. 2. Ecology-Textbooks. I. Moyle, Peter B. II. Title.

QL82.M358 2010

578.68 - dc22

2009050655

Manufactured in China

$\begin{array}{lllllll}16 & 15 & 14 & 13 & 12 & 11 & 10\end{array}$

$\begin{array}{llllllllll}10 & 9 & 8 & 7 & 6 & 5 & 4 & 3 & 2 & 1\end{array}$

The paper used in this publication meets the minimum requirements of ANSI/NISO Z39.48-1992 (R 1997) (Permanence of Paper). () 
If you choose not to be consciously involved in the conservation of forms of life other than your own, you should at least be aware that by doing nothing you are still having an impact on the biota of this planet. The water you drink, the food you eat, the land you live on, and the air you pollute were all obtained at the expense of other creatures. The decisions we make today on how we are going to share these resources will determine which other species will inhabit Earth for the indefinite future.

R. L. Thayer 
This page intentionally left blank 